\title{
WEED CONTROL IN YOUNG MYOGA GINGER
}

\author{
J.M. FOLLETT ${ }^{1}$, J.A. DOUGLAS ${ }^{1}$ and T.K. JAMES ${ }^{2}$ \\ ${ }^{1}$ Crop \& Food Research, Ruakura Agricultural Centre, Private Bag, Hamilton \\ ${ }^{2}$ AgResearch, Ruakura Agricultural Centre, Private Bag, Hamilton
}

\begin{abstract}
Myoga ginger is a traditional Japanese vegetable, currently being evaluated in New Zealand as a possible new export crop. As yet no work has been carried out on the response of myoga to herbicides. This trial evaluated four pre-emergence herbicides viz, oxadiazon, pendimethalin (substituted with pendimethalin+dimethenamid in the second season), linuron+diuron and oxyfluorfen for weed control in establishing stands of myoga ginger. Overall, oxadiazon performed best with good weed control and little or no affect on myoga growth. Linuron+diuron and oxyfluorfen also had little effect on myoga growth but were not as effective in controlling weeds. In the first season, pendimethalin reduced myoga spear numbers and provided relatively poor weed control. In the second season, myoga was tolerant to all pre-emergent herbicides evaluated.
\end{abstract}

Keywords: Myoga, Zingiber mioga, weed control

\section{INTRODUCTION}

Myoga ginger (Zingiber mioga Roscoe) is a perennial member of the ginger family (Zingiberaceae) and a native of Japan. It is grown commercially for the spring shoots and subterranean flower buds produced in autumn. Myoga flower buds are used in soups, tempura, pickled and as a spice with tofu or bean curd (Follett 1986). Production is highly seasonal and there is the capacity to grow this crop in New Zealand in the Japanese off season. High quality shoots and flower buds supplied out of season can fetch high prices on the Japanese market (Douglas and Follett 1992). A number of New Zealand growers are in the early stages of myoga flower bud production.

Myoga overwinters as rhizomes with spears emerging in early September when soil temperatures start to rise. The shoots continue to grow during the spring until the foliage is 1.0 to $1.5 \mathrm{~m}$ tall. In midsummer, subterranean flower buds start to form on ground stems growing from the rhizomes. In the Waikato, the buds are ready for harvest in late February. Flowering begins in the second season after planting. After flowering, the foliage senesces and is killed by winter frosts.

Myoga requires a well drained friable soil, an equitable climate with some winter chilling and approximately $50 \%$ shade (Douglas and Follett 1992). It is propagated by root cuttings (Follett 1991) which are planted out in early spring into beds that have been cultivated and then sprayed with glyphosate and/or paraquat to produce a stale seed bed. After planting, weed control is achieved by mulching and the use of desiccants after crop senescence in winter (Follett 1994).

Although a reasonably vigorous plant root cutting survival and growth are likely to be affected by weed competition. At present no herbicides are registered for use on myoga in New Zealand. In Japan weed control is achieved by hand weeding and the use of a rice straw mulch. The Japanese myoga growers manual (Furuya and Shimomura 1991) does not refer to herbicide use in this crop. The aim of this study was to evaluate a range of pre-emergence herbicides for the control of weeds in myoga during the first and second seasons after establishment to provide growers with a wider range of weed control options. 


\section{MATERIALS AND METHODS}

The trial was carried out at the Blands Horticultural Research Station on a Horotiu sandy loam soil. Prior to planting, the trial area was sprayed with glyphosate to control perennial weeds. This was followed by cultivation with a rotary hoe. Paraquat was sprayed two days prior to planting. On 13 October 1993, $20 \mathrm{~cm}$ long myoga root cuttings were planted at a depth of $10 \mathrm{~cm}$. Cuttings were planted in two rows per flat bed, $15 \mathrm{~cm}$ apart in the row, in rows $12 \mathrm{~cm}$ apart. Beds were $1.2 \mathrm{~m}$ wide and individual plots were $1.5 \times 6.0 \mathrm{~m}$. Treatments included oxadiazon (Forsite), pendimethalin (Stomp), linuron+diuron (Cohort) and oxyfluorfen (Goal) with hand weeded plots as controls. Herbicide application rates, based on known rates required to kill the expected weeds in other crops in the Waikato, are given in Table 1. The treatments were replicated four times in randomised blocks. All treatments were applied with a $\mathrm{CO}_{2}$ powered precision sprayer at $210 \mathrm{kPa}$ in 300 litres water/ha on 10 November 1993. The same treatments (Table 1), except for pendimethalin which was substituted with a pendimethalin/dimethenamid (Wing) mixture, were applied again on 11 November 1994. The control, which consisted of hand weeding, was carried out on 12 November and 10 December 1993, 12 January and 2 February 1994 and 2 February 1995. Hand weeding was carried out using a hoe in the 1993-94 season and by a combination of hoeing and hand pulling in the 1994-95 season.

Shading, achieved by using $50 \%$ shadecloth, which is mandatory for myoga production in New Zealand (Douglas and Follett 1992) was put in place on 17 November 1993.

The effect of these herbicides on myoga were assessed by measuring mean spear height and spear numbers on 24 February 1994 and 30 January 1995. Flower bud yields were measured on 22 March 1994 and on 17 and 28 February and 16 March 1995. Total myoga shoot dry matter yields were determined on 18 April 1995.

The effect of the herbicides on weed growth was assessed by measuring weed dry matter yields on 17 February 1994 and 10 February 1995, and by scoring weed growth on 21 January 1994 and 21 February 1995 . The weed score was a 1 to 100 linear scale incorporating visual assessments of both weed numbers and ground cover.

\section{RESULTS}

In the first season, maximum myoga spear numbers were recorded in plots sprayed with oxadiazon, linuron+diuron and oxyfluorfen. Spear numbers were significantly reduced with the hand weeding and the pendimethalin treatments. In the first season there was no significant difference in the mean spear height or in the number or yield of flower buds (Table 1).

In the second season there was no significant difference in the number or height of spears or flower buds or total shoot yield at the end of the season (Table 1).

In both seasons oxadiazon provided the best weed control with 15.1 and $74 \mathrm{~kg}$ dry matter/ha in 1994 and 1995 respectively and a weed control score of 100 indicating excellent weed control in both 1994 and 1995 (Table 2). Pendimethalin gave the poorest weed control with weed production in 1994 of $674.7 \mathrm{~kg}$ dry matter/ha and a weed control score of 53 caused by grass weeds, most notably summer grass (Digitaria sanguinalis). As a result, dimethenamid was added to the penimethalin treatment during the 1994-95 season. This treatment still provided the poorest weed control with weed production of $750.4 \mathrm{~kg}$ dry matter/ha and a weed control score of 73 .

The crop did not exhibit any visible damage symptoms as a result of using preemergence herbicides.

\section{DISCUSSION AND CONCLUSIONS}

In the first season after establishment, the most effective pre-emergence herbicide was oxadiazon because of its low toxicity to myoga and high level of weed control. Other suitable herbicides were oxyfluorfen and linuron+diuron. After the first establishment year myoga had good tolerance to all pre-emergence herbicides evaluated. Pendimethalin is not recommended because of its effect on myoga growth in the first season and its relatively poor weed control. 
TABLE 1: Myoga spear height (cm), spear numbers, bud yield (kg/ha), bud numbers and shoot yield (tDM/ha) after treatment with preemergence herbicides over two seasons.

\begin{tabular}{|c|c|c|c|c|c|c|}
\hline Treatment & $\begin{array}{c}\text { Rate } \\
\text { (kg ai/ha) }\end{array}$ & $\begin{array}{l}\text { Spear } \\
\text { height }\end{array}$ & $\begin{array}{l}\text { Spear no. } \\
\text { (x1000/ha) }\end{array}$ & $\begin{array}{l}\text { Bud } \\
\text { yield }\end{array}$ & $\begin{array}{c}\text { Bud no. } \\
\text { (x1000/ha) }\end{array}$ & $\begin{array}{l}\text { Shoot } \\
\text { yield }\end{array}$ \\
\hline \multicolumn{7}{|c|}{ 1993-94 season } \\
\hline hand weeded & & 52.4 & 180 & 69 & 9 & - \\
\hline oxadiazon & 4.0 & 43.7 & 250 & 94 & 9 & - \\
\hline pendimethalin & 4.0 & 54.8 & 180 & 45 & 5 & - \\
\hline linuron+diuron & 6.0 & 46.6 & 250 & 118 & 13 & - \\
\hline oxyfluorfen & 3.0 & 42.3 & 260 & 98 & 11 & - \\
\hline SED & & $5.68 \mathrm{NS}$ & $19.9 * *$ & 49.0NS & $4.6 \mathrm{NS}$ & \\
\hline \multicolumn{7}{|c|}{ 1994-95 season } \\
\hline hand weeded & & 67.5 & 390 & 13 & 3 & 127.8 \\
\hline oxadiazon & 4.0 & 65.1 & 350 & 439 & 55 & 190.3 \\
\hline $\begin{array}{l}\text { pendimethalin+ } \\
\text { dimethenamid }\end{array}$ & 5.0 & 59.6 & 290 & 207 & 15 & 150.8 \\
\hline linuron+diuron & 6.0 & 71.8 & 390 & 175 & 18 & 91.9 \\
\hline oxyfluorfen & 3.0 & 62.1 & 420 & 396 & 38 & 176.2 \\
\hline SED & & $9.30 \mathrm{NS}$ & $72.5 \mathrm{NS}$ & $193.9 \mathrm{NS}$ & $20.5 \mathrm{NS}$ & $41.35 \mathrm{NS}$ \\
\hline
\end{tabular}

NS Treatments not significantly different at $5 \%$ level

** Treatments significant at $1 \%$ level

TABLE 2: Weed dry matter ( $\mathrm{kg} / \mathrm{ha})$ and weed control score ${ }^{1}$ in myoga treated with pre-emergence herbicides over two seasons.

\begin{tabular}{|c|c|c|c|c|c|}
\hline \multirow[t]{2}{*}{ Treatment } & \multirow[t]{2}{*}{$\begin{array}{c}\text { Rate } \\
\text { (kg ai/ha) }\end{array}$} & \multicolumn{2}{|c|}{ Weed DM } & \multicolumn{2}{|c|}{$\begin{array}{l}\text { Weed Control } \\
\text { Score }^{1}\end{array}$} \\
\hline & & 17.2 .94 & 10.2 .95 & 21.1 .94 & 21.2 .95 \\
\hline hand weeded & & 267.0 & 432.6 & 80 & 81 \\
\hline $\begin{array}{l}\text { oxadiazon } \\
\text { pendimethalin }\end{array}$ & 4.0 & 15.1 & 74.0 & 100 & 100 \\
\hline+ dimethenamid $^{2}$ & 4.0 & 674.7 & 750.4 & 53 & 73 \\
\hline linuron+diuron & 6.0 & 122.1 & 298.1 & 90 & 78 \\
\hline oxyfluorfen & 3.0 & 110.3 & 288.8 & 93 & 83 \\
\hline SED & & $193.6^{*}$ & $174.6^{*}$ & $13.3 *$ & $7.6^{*}$ \\
\hline
\end{tabular}

$1100=$ excellent weed control; $0=$ no weed control

2 Pendimethalin alone in 1993

* Treatments significant at $5 \%$ level

Hand weeding reduced the number of spears in the first season probably because of damage to emerging spears. Hand weeding in the second season did not reduce the number of spears because weeds were removed later in season when they could be pulled rather than hoed out.

The availability of an effective pre-emergence herbicide along with a stale seed bed before planting should provide the New Zealand myoga grower with an effective means of weed control at establishment. This will allow mulching to be delayed until the second season when it can be used primarily for flower bud protection rather than for weed control.

In established crops, rhizome growth is rapid (Douglas and Follett 1992). High crop vigour together with the $50 \%$ shade required for myoga growth, results in many 
weeds being shaded out. The ability to use several pre-emergent herbicides as well as winter clean-up treatments and the agronomic requirement of a mulch for bud production means weed control should not be a problem with this crop.

\section{ACKNOWLEDGEMENTS}

Thanks to Kirsty Lyall for technical assistance

\section{REFERENCES}

Douglas J.A. and Follett J.M., 1992. Myoga ginger-a new export crop for New Zealand. Proc. Agronomy Soc. of N.Z. 22: 71-73.

Follett J.M., 1986. Production of four traditional Japanese vegetables in Japan. Ruakura Agricultural Centre, Hamilton. Special Publication.

Follett J.M., 1991. Propagation notes for some new and novel crops introduced into New Zealand. Comb. Proc. Int. Plant Prop. Soc. 41: 104-109.

Follett J.M., 1994. Myoga production in New Zealand. Comb. Proc. Int. Plant Prop. Soc. 44: 373-376.

Furuya K. and Shimomura S., 1991. Myoga: three methods of cultivation. Nosangyogyosonbunka Kyokai, Tokyo, 133 pp. 